\title{
Experimental evaluation of the thermal and hygrometric behavior of a Colombian greenhouse used for the production of roses (Rosa spp.)
}

\author{
Edwin Villagran ${ }^{1 *}$, Carlos Bojacá ${ }^{2}$
}

\begin{abstract}
The spatial behavior of the environmental variables involved in rose production is one of the factors of greatest current interest in the Colombian ornamental sector. The aim of this work consisted in the evaluation of a passive greenhouse through an experimental approach that included the capture and recording of data through a grid of 40 sensors homogeneously distributed inside the greenhouse. The data processing was carried out through the application of geostatistical techniques that allowed to obtain contour plots for 5 levels of radiation intensity. The results of the exploratory analysis showed that the behavior of temperature, relative humidity and vapour pressure deficit are not the most suitable for rose production, mainly for the conditions of the night period where the temperature exhibited values below $12.5^{\circ} \mathrm{C}$, the relative humidity was above $90 \%$ and the vapour pressure deficit was below 0.1 $\mathrm{kPa}$. On the other hand in the structural analysis the circular model of theoretical semivariogram was the one that better degree of adjustment presented in comparison with the experimental data finding that a strong spatial dependency exists for the studied variables, the prediction of the not sampled points was made by means of the method of ordinary kriging finding that horizontal gradients of temperature and relative humidity exist inside the greenhouse that increases in magnitude according to the level of radiation arriving to reach values of $6.1{ }^{\circ} \mathrm{C}$ and $30.4 \%$.
\end{abstract}

Keywords: geostatistics, microclimate, kriging, spatial variability.

Resumo

Avaliação experimental do desempenho térmico e higrométrico em estufa colombiana utilizada para a produção de rosas (Rosa spp.).

O desempenho espacial das variáveis ambientais envolvidas na produção de rosas é um dos fatores de maior interesse atual no setor ornamental colombiano. O objetivo deste trabalho foi a avaliação de uma estufa passiva através de uma abordagem experimental que incluiu a captura e registro de dados através de uma rede de 40 sensores uniformemente distribuídos dentro da estufa. O processamento de dados foi feito através da aplicação de técnicas geoestatísticas que permitiram a obtenção de gráficos de contorno para 5 níveis de intensidade de radiação. Os resultados da análise exploratória mostraram que o desempenho da temperatura, umidade relativa e déficit de pressão de vapor não são os mais adequados para a produção de rosas, principalmente para as condições do período noturno em que a temperatura apresentou valores abaixo de $12,5^{\circ} \mathrm{C}$, a umidade relativa estava acima de $90 \%$ e o déficit de pressão de vapor estava abaixo de $0,1 \mathrm{kPa}$. Por outro lado, na análise estrutural, o modelo circular do semivariograma teórico foi o que apresentou o melhor grau de ajuste em relação aos dados experimentais, encontrando que existe uma forte dependência espacial para as variáveis estudadas. A previsão dos pontos não amostrados foi feita através do método de kriging ordinário, encontrando que existem gradientes horizontais de temperatura e umidade relativa dentro da estufa que aumentam de magnitude de acordo com o nível de radiação, atingindo valores de $6.1^{\circ} \mathrm{C}$ e $30.4 \%$.

Palavras-chave: geoestatística, microclima, kriging, variabilidade espacial.

\section{Introduction}

The rose is a semi-climbing woody plant that produces flowers. It belongs to the Rosaceae family and is considered one of the four most important cut flowers in the world. There are approximately 200 species and 20.000 cultivars of rose, is the most traded flower in the international market mainly for its ornamental beauty its variety of colors and aromas, likewise its uses ranging from the ornamental industry to the pharmaceutical industry and food (Dotto et al., 2016; Reis et al., 2016; Deng et al., 2019; Gil et al., 2019; Qiu et al., 2019).

\footnotetext{
${ }^{1}$ Universidad Jorge Tadeo Lozano, Facultad de Ciencias Naturales e Ingeniería, Departamento de Ciencias Biológicas y Ambientales, Bogotá, Colombia. *Corresponding autor: edwina.villagranm@utadeo.edu.co

${ }^{2}$ Universidad Jorge Tadeo Lozano, Departamento de Ciencias Básicas y Modelado, Facultad de Ciencias Naturales e Ingeniería, Bogotá, Colombia.
}

Received Fev 13, 2020 | Accepted Apr 21, 2020| Available online May 11, 2020

Licensed by CC BY 4.0

https://doi.org/10.1590/2447-536X.v26i2.2149

Area Editor: Márkilla Zunete Beckmann-Cavalcante 
Colombia is the second largest exporter of flowers after the Netherlands, its share of the international market is $16 \%$ of the world total. According to statistics from the Ministry of Agriculture and Rural Development (MADR) the main destination country for Colombian flowers is the United States with $78.1 \%$. In a second line are located Japan, United Kingdom, Canada, Netherlands, Spain and Russia all with a share of less than $4 \%$ of total sales. The area of cultivation under glass of the sector for the year 2018 was 8,433 hectares where a total of 239.497 tons of stems were produced for export generating foreign exchange earnings to the country of 1,403 million dollars, where the rose participated with a $23.8 \%$ which is equivalent to 333.8 million dollars (MADR, 2019). The Colombian ornamental sector has been established since its origins in a productive system under cover where passive greenhouses with natural ventilation predominate (Villagrán and Bojacá, 2019a, 2019c).

A passive greenhouse is an agricultural construction with a translucent roof, where solar radiation is used to generate a favorable microclimate for plant growth and development (Choab et al., 2019). A microclimate is understood to be a series of climatic parameters that are formed in the environment near a plant and are generated from a series of relationships involving heat and mass transfer, this microclimate has a direct relationship with the metabolic activities of the plant and therefore in the final crop yields (Singh et al., 2018; Villagran Munar et al., 2018). The implementation of a greenhouse additionally seeks to provide crop protection from biotic and abiotic factors, which promotes an increase in the quantity and quality of the final product harvested compared to open field production (Villagrán et al., 2019; Zhang et al., 2019). For rose production under greenhouse the following microclimate conditions are recommended as being optimal for production, the temperature value should be between 18 and $25{ }^{\circ} \mathrm{C}$ for the day period (Kinfe et al, 2014) and for the night period between 14 and $18{ }^{\circ} \mathrm{C}$ (Reid, 2008), on the other hand it is appropriate that the relative humidity conditions are above $70 \%$ during the day and maximum $85 \%$ at night (Torre and Fjeld, 2001), likewise the value of the vapour pressure deficit should be between 0.4 and 1.2 $\mathrm{kPa}$ for the day and between 0.2 and $0.4 \mathrm{kPa}$ for the night (Konopacki et al., 2018).

The study of the microclimate in greenhouses for the purposes of characterization and management has been one of the themes most worked on by researchers in this area of knowledge (Li et al., 2019). The methodological approach of these studies is diverse and includes experimentation on real or scale structures, computer modeling and simulation through numerical tools or energy and mass balance models, and experimental approaches include the capture and recording of data at some specific sites of the greenhouse studied (Villagrán et al., 2019). The microclimate depends on intrinsic characteristics of the structure such as: geometry, shape, size, height, orientation and roofing material and extrinsic factors such as the climatic conditions of the outside environment (Villagrán and Bojacá, 2019b).
One of the main disadvantages of passive greenhouses is the heterogeneity of the microclimate, which can generate negative impacts on agricultural production and affect commercial quality parameters in the case of the rose, such as stem length and diameter, size, color and health of the flower head, and finally a reduction in vase life in the postharvest stage, where in a few days alterations are generated, such as wilting, discoloration and abscission of the flower petals, as well as bending of the flower neck and stem-end browning (Ahemd et al., 2016; In et al., 2016; Valencia et al., 2018). Recent concerns related to crop quality and uniformity require consideration of the heterogeneity of flow patterns and moisture and temperature distributions in the greenhouse due to the effects on transpiration rates and plant nutrient uptake (Taki et al., 2016; Ma et al., 2019; Saberian and Sajadiye, 2019). On the other hand, other studies have concluded that the heterogeneous microclimatic behavior can cause problems related to the health and physical integrity of the workers since it can generate affectations mainly on the cardiovascular and thermoregulatory systems (Diano et al., 2016; García-Ruiz et al., 2018).

At the local level in a study developed by Bojacá et al. (2009b) the authors found that there is a spatial variation in temperature in a horizontal profile located $1.5 \mathrm{~m}$ above ground level of up to 3.2 and $3.5^{\circ} \mathrm{C}$ for the two greenhouses evaluated. Subsequently under study in a small French greenhouse with a covered surface area of $40 \mathrm{~m}^{2}$ by Fatnassi et al. (2012) the researchers reported that there are spatial variations in horizontal temperature of up to 5 ${ }^{\circ} \mathrm{C}$. Likewise, other studies in which wireless sensor and monitoring networks were used, such as the one developed by Balendonck et al. (2014) reported variations of $5^{\circ} \mathrm{C}$ and $20 \%$ and for the case of a greenhouse located in Greece the average values of variation were $3.3{ }^{\circ} \mathrm{C}$ and $9 \%$ (Ferentinos et al., 2017). Climate heterogeneity can also occur in the vertical profile of the greenhouse García-Ruiz et al. (2018) reported differences with an average value of 2 to $4{ }^{\circ} \mathrm{C}$ in a raspa-type greenhouse located in Almeria Spain.

The main objective of this research was to characterize the thermal and hygrometric behavior inside a commercial greenhouse used for rose production in the savannah of Bogota Colombia. The methodological approach included the use of geostatistical techniques for the analysis of the experimental information collected.

\section{Materials and methods}

\section{Characteristics of the greenhouse and collection of meteorological information}

The experimental work was developed in the savannah of Bogota Colombia in a traditional plastic-covered greenhouse of the so-called multi-tunnel type with a covered area of $5610 \mathrm{~m}^{2}$, belonging to a rose producing

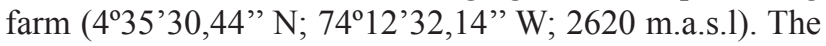
greenhouse was made up of 15 semi-detached spans, each $6.8 \mathrm{~m}$ wide (Figure 1A-B). The minimum and maximum 
heights under the gutter were 3.0 and $8.2 \mathrm{~m}$, respectively, the longitudinal distance of the greenhouse was $55 \mathrm{~m}$ and it was oriented East-West. Each span had a fixed roof ventilation area with an opening of $0.63 \mathrm{~m}$; the total natural ventilation area was complemented by $2.5 \mathrm{~m}$ openings on all four sides of the structure, for a total ventilation area of $1314.3 \mathrm{~m}^{2}$, which corresponds to $23.4 \%$ of the total area covered by the greenhouse.

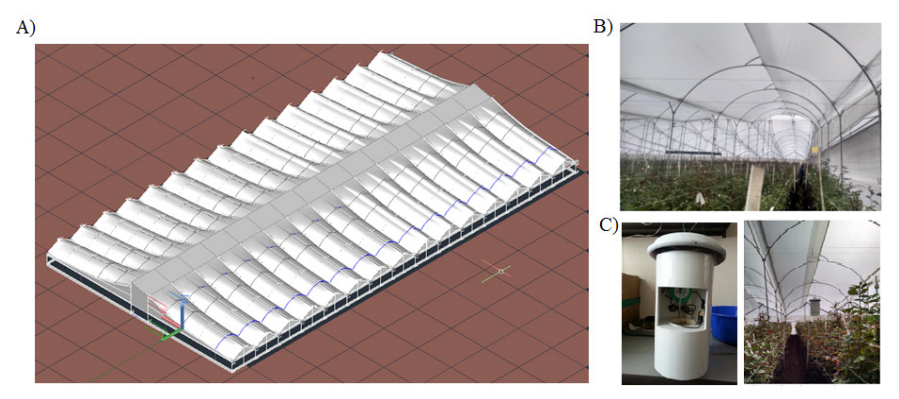

Figure 1. A) Diagram of the evaluated greenhouse, B) Interior of the inverter and C) Measurement sensors.

Weather conditions in the greenhouse outdoor environment such as solar radiation, air temperature and humidity, wind speed and direction were recorded and stored by means of an automatic weather station i-Metos Compact station (Pessl Instruments $\mathrm{GmbH}$, Weiz, Austria). Inside the greenhouse 40 type-T copper thermocouples used to measure dry bulb and wet bulb temperatures were distributed and stored in a data logger (Cox-Tracer Junior, Escort DLS, Edison, NJ, EE. UU.). The thermocouples were arranged in a ventilated capsule that acted as a shield from direct solar radiation (Figure 1C). The data collection points inside the greenhouse were distributed in a regular grid in the horizontal direction at a height of $1.7 \mathrm{~m}$ above ground level and with a cell size of $11 \times 12.75 \mathrm{~m}$, thus having a sampling point every $140.25 \mathrm{~m}^{2}$. Both outside and inside, the frequency of measurement and data recording was 10 minutes during the period from June 1 to July 9, 2018. This measurement period can be considered representative for the study region since it is a country located in an intertropical zone, where variations of the main climate variables are not as drastic as in other regions where seasons occur. The savannah of Bogota presents climatic characteristics for a period of 30 years where the average annual temperature is $14{ }^{\circ} \mathrm{C}$ and where the monthly variations are less than $1{ }^{\circ} \mathrm{C}$, for its part the precipitation presents an accumulated average of $853 \mathrm{~mm}_{\text {year-1 }}$ (López, 2016; Moreno and Perdomo, 2018).

\section{Geostatistical analysis}

An analysis using geostatistical techniques generally consists of three main stages: exploratory analysis of the data, analysis of the spatial relationship or structural analysis and finally the estimation or simulation of data better known as prediction. For the measurement period, depending on the intensity levels of the external solar radiation, the data obtained was grouped into 5 radiation levels $\left(\mathrm{W} \mathrm{m}^{-2}\right)$, including the night which corresponds to group 1 of $0 \mathrm{~W} \mathrm{~m}^{-2}$, the other 4 radiation levels were determined by calculating the quartiles of the data set (Table 1). Each hourly average data set was then grouped into one of the five radiation levels for subsequent geostatistical analysis.

\section{Exploratory analysis}

This first step is generally carried out in order to fulfil several purposes, among the most important: to verify some assumptions of geostatistics such as stationarity and periodicity. In this phase of the process, graphs are usually used to inspect the stationarity of the variable of interest (Isaaks and Srivastava, 1989). It is also of great interest to verify if the data are seasonal, that is, if they present a periodic behavior. To do this, it is assumed that the degree of association of these data is a function of the spatial separation and not of the location of these data in space. Additionally, basic statistics are used, in this case the Shapiro-Wilk test, to determine the statistical distribution of the data and to verify that they comply with the assumption of normality which, together with the initial graphical analysis, allows us to verify that the data do not have any tendency in space. For the calculation and subsequent analysis of the distribution of relative humidity (HR) and the vapour pressure deficit (VDP), the following psychrometric relations proposed by Huang et al. (2013) and used by Čereković et al. (2014). 


\section{Structural analysis}

In this stage we seek to determine a spatial dependence function that is valid for the empirical semivariate. The graphic relationship between the spatial separation distances and the semivariate of the variable studied is known as the semivariogram (Bojacá et al., 2009b). The empirical semivariograms are constructed using the following equation.

$$
\gamma(h)=\frac{1}{2 N p(h)} \sum_{i=1}^{N p(h)}[Z(x i)-Z(x i+h)]^{2}
$$

Where: $N p_{h}$ is the number of pairs at a distance, is the increase, are the experimental values and are the experimental values and the locations where the values are measured ).

The shape of the empirical omnidirectional semivariogram can be adjusted to a variety of theoretical semiviogram models. For the analysis of these data sets, the performance of the following models was evaluated: circular, cauchy, exponential, spherical and Gaussian. The basic parameters of this type of models are; range $(a)$, sill $\left(c_{1}\right)$ y nugget $\left(c_{0)}\right.$. The sill represents the upper asymptote of the semivariogram and corresponds to the maximum variability explained by the semivariogram, the range represents a measure of the maximum influence distance and the nugget represents both the sampling error and the spatial variability for the minimum distance interval (Bojacá et al., 2009b). The selection of the semivariogram model used to make the prediction was made through the analysis of the following criteria, Akaike's information criterion (AIC) and the Bayesian information criterion (BIC). The models that presented the lowest values for these two adjustment criteria were selected as the theoretical semivariogram model that best represents the data set evaluated inside the greenhouse.

\section{Prediction}

In this stage, the information collected in the previous stages is used to make estimates of the variables, i.e. to predict the variables of interest at non-sampled points based on known values and their spatial continuity structure. The predominant estimation method is kriging by the ordinary method, which is considered as an optimal, unbiased and minimum variance linear predictor where the prediction is given by the following equation:

$$
\mathrm{Z}\left(\mathrm{x}_{0}\right)=\sum^{\mathrm{n}} \lambda_{\mathrm{i}} \mathrm{Z}\left(\mathrm{x}_{\mathrm{i}}\right) \quad \text { con } \quad \sum_{\mathrm{i}=1}^{\mathrm{n}} \lambda_{\mathrm{i}}=1
$$

Where: $\lambda_{i}$ are the weights that are assigned to each value of the variable in the observed positions $Z\left(x_{0}\right)$ based on the parameters of the previously adjusted theoretical semivariogram (Cressie, 1992). Once this procedure has been carried out, maps are drawn up showing the representation of the variable of interest, where the main types of maps used are contour distribution maps.

\section{Results and Discussion}

\section{Exploratory analysis}

From the information taken in the field, the data of the three variables under study were grouped according to solar radiation. In this way, for the external solar radiation recorded during the measurement period, the quartiles were calculated excluding the solar radiation recorded during the night time as it is equal to zero, in total the data were grouped in 5 levels of radiation (Table 1). These are upper limits of the radiation level at which the data of the climate variables under study were grouped for subsequent analysis using geostatistical methods. This exploratory analysis was performed for a total of 15 experimental data sets corresponding to a sensor grid located at a height of 1.7 $\mathrm{m}$, for 5 data sets (Table 1) of three variables (Temperature, Relative Humidity and Vapour Pressure Deficit).

Table 1. Upper limit of the global solar radiation levels $\left(\mathrm{W} \mathrm{m}^{-2}\right)$ in which the temperature, relative humidity and VPD records were grouped for spatial statistical analysis.

\begin{tabular}{|c|c|c|c|c|c|}
\hline & Grupo 1 & Grupo 2 & Grupo 3 & Grupo 4 & Grupo 5 \\
\hline $\begin{array}{c}\text { Radiation level } \\
\left(\mathrm{Wm}^{-2}\right)\end{array}$ & 0 & 76.08 & 261.92 & 413.04 & 815.33 \\
\hline
\end{tabular}

\section{Temperature}

The mean temperature for the 24-hour sensor grid installed in the greenhouse was $14.3{ }^{\circ} \mathrm{C}$ during the measurement period, which is $0.9{ }^{\circ} \mathrm{C}$ higher than the mean temperature of the outside environment (Figure 2A). When separating the behaviour during the day and the night, it is observed that for the night period the behaviour of the temperature inside the greenhouse was similar to that of the temperature outside, obtaining values of 11.6 and $11.5{ }^{\circ} \mathrm{C}$ respectively, on the other hand, for the day period the average value of the temperature inside was $16.9{ }^{\circ} \mathrm{C}$ while in the outside 
environment it was $15.2{ }^{\circ} \mathrm{C}$ (Figure 2A). The daytime thermal behaviour can be considered acceptable for rose production between 9 and 16 hours where the temperature value is above the minimum recommended value of $17{ }^{\circ} \mathrm{C}$ for rose production, but well below the recommended optimum value of $24{ }^{\circ} \mathrm{C}$, this will result in longer growing cycles (Villagrán and Bojacá, 2019a). It should also be noted that the thermal behaviour at night is not suitable for the production of roses as they have average values of less than $12.5^{\circ} \mathrm{C}$ inside the greenhouse, which is below the minimum recommended value for rose production of $14{ }^{\circ} \mathrm{C}$ (Reid, 2008). This will influence the growth rate of the crop and its final yield and additionally the number of stems can be expected to increase with the presence of bull's head flowers which are not of commercial interest (Villagrán and Bojacá, 2019b).
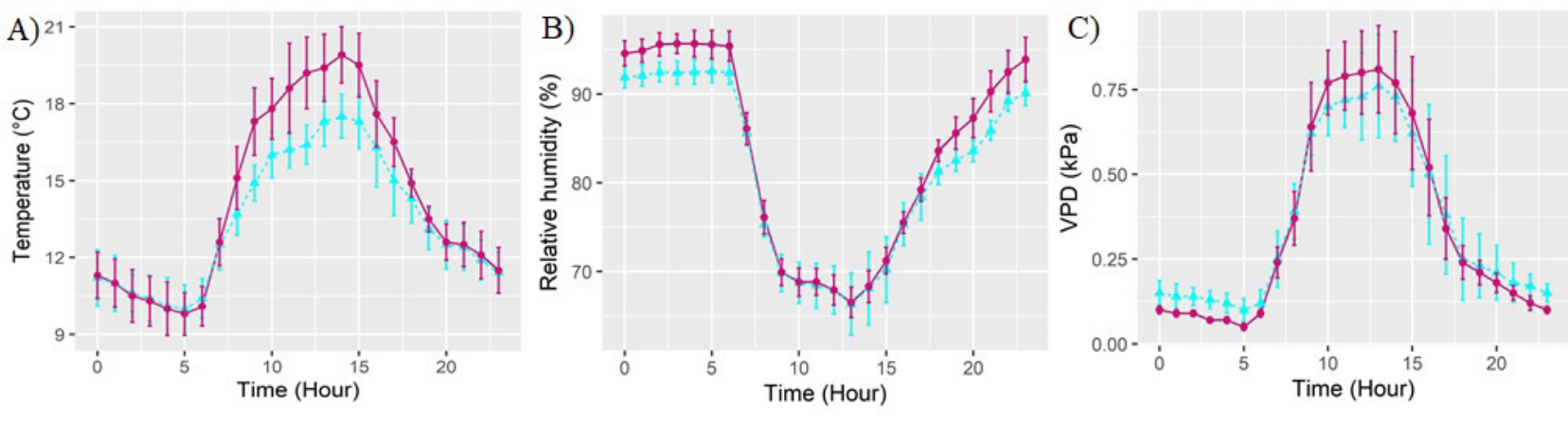

Location $\rightarrow$ Greenhouse - Outside

Figure 2. Time behavior of variables evaluated in the inside and outside environment of the greenhouse, A) Temperature $\left.\left({ }^{\circ} \mathrm{C}\right), \mathrm{B}\right)$ Relative humidity $(\%)$ and C) VPD $(\mathrm{kPa})$.

The scatter plots as a function of spatial coordinates for the data obtained from the temperatures of the radiation group 5 dataset (Figure 3A-B) were constructed in order to detect some kind of trend. In this figure it can be seen that there is no considerable trend in any of the $\mathrm{X}$ or $\mathrm{Y}$ coordinates. Likewise, the histogram of the data grouped for this level of radiation can be seen (Figure 3C). In principle, it can be inferred that, due to the bell shape that the histogram takes, there is an adjustment to the normality of the data set; additionally, to confirm the assumption of normality, the Shapiro-Wilk test was performed, where it is established that the value of $\mathrm{p}$ must be greater than the defined alpha (0.05), obtaining a value of $\mathrm{p}=0.3416$, which validates the assumption of normality for this data set.
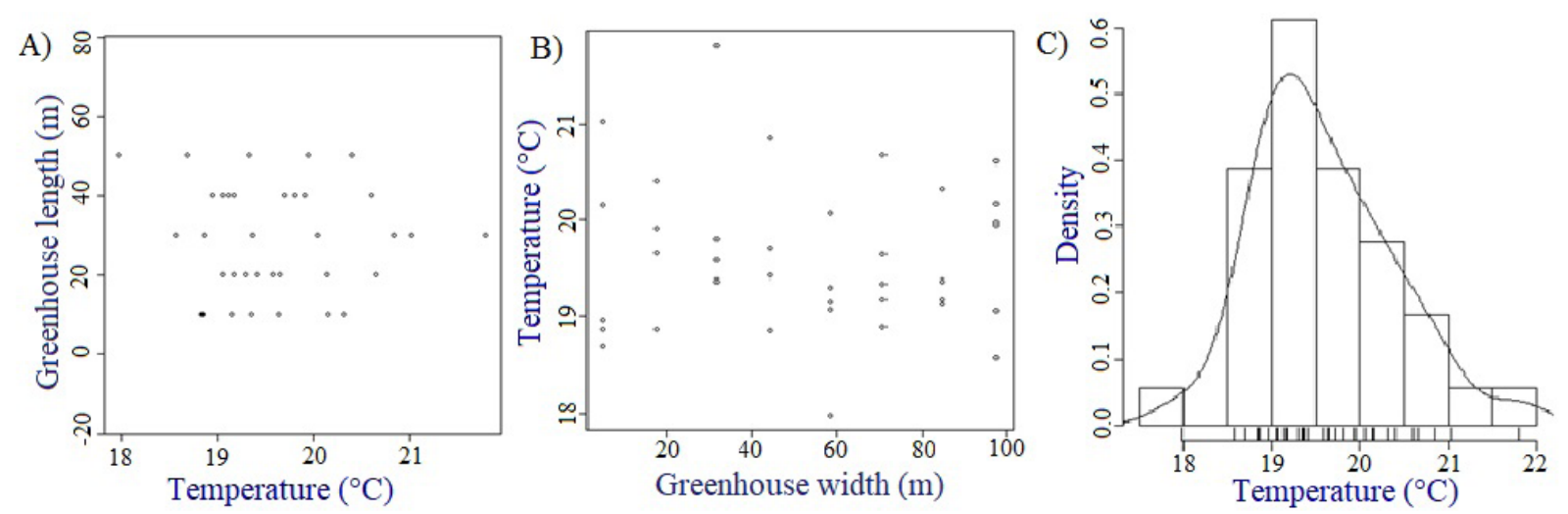

Figure 3. Results of the spatial exploratory analysis of the temperatures recorded by the sensor grid and grouped in radiation group 5 [413.04 - 815.33 $\left.\mathrm{W} \mathrm{m}^{-2}\right]$. 


\section{Relative humidity}

The average relative humidity behavior in the indoor and outdoor environment of the greenhouse was $86.0 \%$ and $84.7 \%$ for 24 hours a day during the measurement period (Figure 2B). The mean values of relative humidity obtained in the greenhouse for the hours of the daytime period in the external and internal environment of the greenhouse were $79.2 \%$ and $79.5 \%$ respectively, while for the nighttime hours values of $90.3 \%$ and $92.7 \%$ were obtained, in general the highest mean relative humidity values inside the greenhouse are due to the contribution of humidity by transfer of mass due to transpiration phenomena in the crop and the evaporation of irrigation water from the soil. For this variable should be mentioned that the relative humidity values are higher than the recommended value for the production of rose that should be $70 \%$, although this feature is common to the outdoor climate of the savannah of Bogota, this high relative humidity levels definitely help the proliferation of fungal diseases in the foliage and flowers of the crop, within these diseases of strong incidence at the local level are the gray mold and downy mildew, caused by Botrytis cinerea and Peronospora sparsa, respectively these diseases have the capacity to generate devastating damages on the plants, generating relevant production losses (Bautista et al., 2016).

The results obtained for the relative humidity as well as for the temperature did not show any tendency in the spatial directions $X, Y$. This can be seen in the scatter diagrams obtained for the radiation group 3 (Figure 4A-B). The histogram obtained for the data set (Figure 4C) allows us to observe that the graph presents a characteristic distribution of data adjusted to the normal, which was confirmed with the value obtained of $\mathrm{p}$ in the Shapiro-Wilk test that exhibited a value equal to 0.4668 .
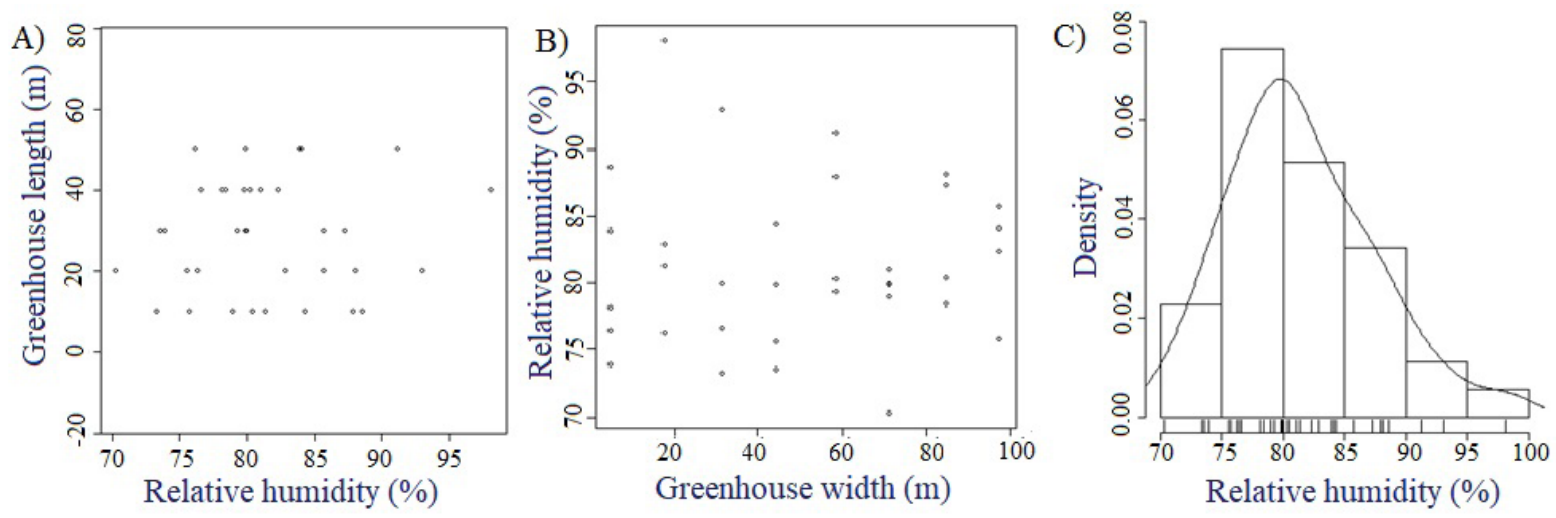

Figure 4. Results of spatial exploratory analysis of relative humidity recorded by the sensor grid and grouped in radiation group $3\left[76.08-261.92 \mathrm{~W} \mathrm{~m}^{-2}\right.$ ).

Vapour Pressure Deficit (VPD)

The behavior of the average DPV value for 24 hours a day in the external and internal environment of the greenhouse showed values of 0.26 and $0.25 \mathrm{kPa}$ respectively (Figure $2 \mathrm{C})$. The behavior for the daytime period showed values of 0.38 and $0.39 \mathrm{kPa}$, while for the nighttime hours it was 0.13 and $0.10 \mathrm{kPa}$ for the environment outside and inside the greenhouse, respectively.

In the case of the behavior of this variable, as in the previous cases, no significant spatial trend was found in either of the two coordinates evaluated (Figure 5A-B). The distribution obtained for the data set corresponding to radiation group 4 can be found in this graph. The normality of the data was verified graphically (Figure 5C) which was validated by obtaining a $p$ value equal to 0.7214 . This same procedure was verified in the 15 sets of data evaluated, obtaining results like those discussed. Therefore, we proceed to the next phase of geostatistical analysis which is to construct the omnidirectional semivariogram. The VPD levels inside the greenhouse are not the most suitable for rose production, since it is recommended that the values of this variable are located in a range of 0.4 and $1.2 \mathrm{kPa}$, this in order to limit as much as possible negative effects on the photosynthetic rate of the plant and the generation of an environment favorable to the emergence and survival of fungal diseases (Konopacki et al., 2018). Low VPD values also affect plant nutrition by causing deficiencies influenced by poor movement of sap flow (Shamshiri et al., 2018). 

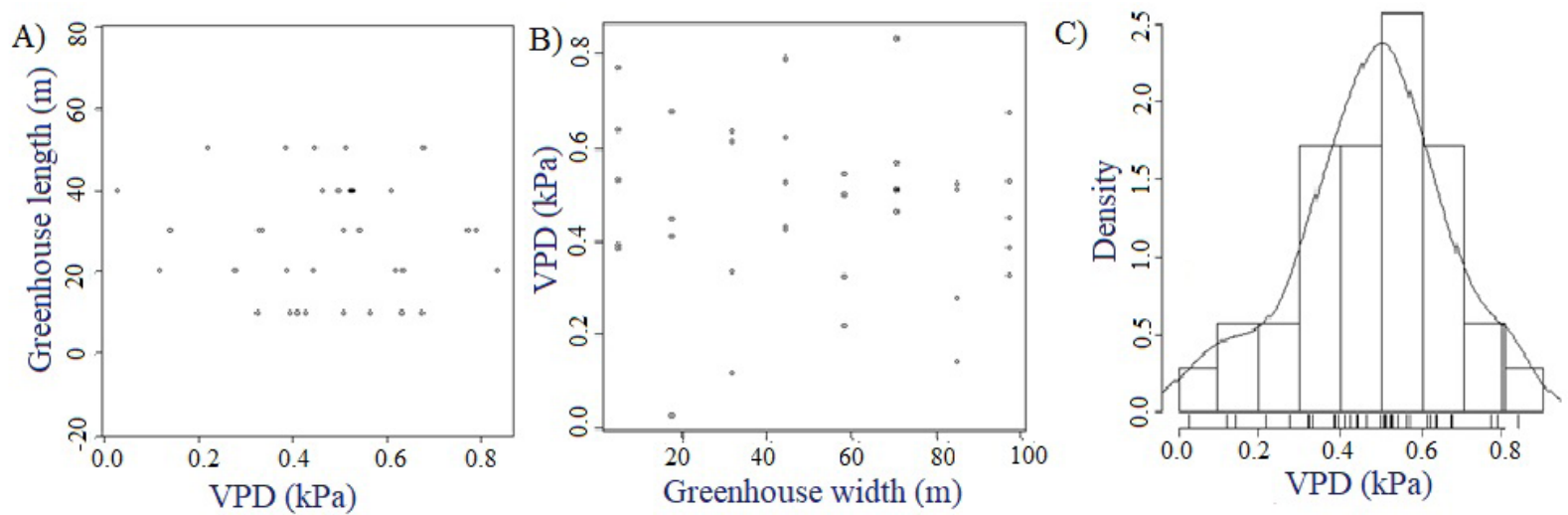

Figure 5. Results of the exploratory spatial analysis of the vapour pressure deficit recorded by the sensor grid and gathered in radiation group $4\left[261.92-413.04 \mathrm{~W} \mathrm{~m}^{-2}\right.$ ).

\section{Structural analysis}

Temperature

The results obtained for this phase of the geostatistical analysis indicated that as the levels of radiation increase, the values of semivariate are greater, this will be translated into a behavior with greater variation of the temperature at spatial level inside the greenhouse, likewise the semivariograms obtained for the hours of the night and at low levels of radiation as those that are presented in the dawn or the dusk of the day exhibited a smaller range of variation of the internal temperature of the greenhouse, this results coincide with the obtained in the developed study Bojacá et al. (2009a). Of the theoretical semivariogram models used to fit the data of the empirical semivariograms, it was established that the circular model best represented the observed values for $80 \%$ of the radiation level groups into which the data were divided, and the group with the highest degree of fit was group 2, while for radiation group 4 the values of AIC and BIC indicated a better degree of fit in the spherical model (Table 2).

Table 2. Parameters of the selected theoretical semivariogram model and its fit quality measures (Akaike - AIC and Bayesian - BIC information criteria) for the assessed greenhouse temperature data sets.

\begin{tabular}{|c|c|c|c|c|c|c|c|}
\hline Group & Model & Nugget $\left(c_{0}\right)$ & Sill $\quad\left(c_{1}\right)$ & $\left(c_{0 /} c_{1)}(\%)\right.$ & Range $(a, \mathrm{~m})$ & AIC & BIC \\
\hline 1 & Circular & 0.02 & 0.13 & 15.38 & 9.97 & 125.11 & 131.60 \\
\hline 2 & Circular & 0.0 & 0.18 & 0.00 & 13.42 & 48.42 & 54.63 \\
\hline 3 & Circular & 0.06 & 0.34 & 17.64 & 9.45 & 94.71 & 101.72 \\
\hline 4 & Spherical & 0.11 & 0.59 & 18.64 & 9.88 & 99.45 & 105.97 \\
\hline 5 & Circular & 0.0 & 0.92 & 0.00 & 15.39 & 108.47 & 114.93 \\
\hline
\end{tabular}

The values of the parameter $c_{0}$ for the groups 2 and 5 were equal to zero while for the other groups values between 0.08 and 0.11 were obtained, these values of nugget effect with low magnitude indicate that only a small part of the spatial dependence is due to an experimental error. The behaviour of the sill parameter $\left(c_{1}\right)$ evidence that there is a greater spatial variation in temperature as the level of radiation increases, the value of $c$, showed an increasing behaviour depending on the level of radiation evaluated. The range values $(a)$ were found between 9.45 and $15.39 \mathrm{~m}$, where particularly two groups are differentiated. A first group groups the values of $a$ for groups 1, 3 and 4 where values were established around $9.5 \mathrm{~m}$ while the two remaining sets indicated values of $a$ around $14 \mathrm{~m}$. In that sense, a greater spatial dependence on temperature between closer points is to be expected when radiation levels correspond to groups 1, 3 and 4 . The results of the relationship $c_{0} c_{1}$ with values below $25 \%$ indicate a strong spatial dependence (Cambardella et al., 1994). 


\section{Relative humidity}

For this case the circular model was the theoretical semivariogram model that indicated the best degree of adjustment for the data observed experimentally, this model was the one that presented the lowest values of AIC and BIC (Table 3). The values of $c_{0}$ were equal to zero for most of the data sets except for what was found for group 3. The values for the parameter $c$, show a clear incremental trend as radiation levels increase. As in the cases previously reported, a higher value of $c$, will result in a greater spatial variation of the variable. The values of $c_{1}$ oscillate by 7.74 for group 1 and reach a semivariate value of 84.34 for group 5. This describes a greater variance of the variable as radiation levels increase. The spatial dependence is around $13 \mathrm{~m}$ for all the data sets except for group 3 where the spatial dependence between two points was around $10 \mathrm{~m}$, on the other hand, the results between 0 and $9 \%$ of the relationship $c_{0 /} c_{1}$ show that there is a strongly structured spatial dependence.

Table 3. Parameters of the selected theoretical semivariogram model and its fit quality measures (Akaike - AIC and Bayesian - BIC information criteria) for the relative humidity data sets.

\begin{tabular}{|c|l|c|c|c|c|c|c|c|}
\hline Group & Model & Nugget $\left(\boldsymbol{c}_{\boldsymbol{0}}\right)$ & Sill & $\left(\boldsymbol{c}_{\boldsymbol{l}}\right)$ & $\left(\boldsymbol{c}_{\boldsymbol{\prime}} \boldsymbol{c}_{\boldsymbol{l}} \mathbf{(} \mathbf{( \% )}\right.$ & Range $(\boldsymbol{a}, \mathbf{m})$ & AIC & BIC \\
\hline 1 & Circular & 0.0 & 7.74 & 0.00 & 12.95 & 168.92 & 174.91 \\
\hline 2 & Circular & 0.0 & 10.50 & 0.00 & 13.61 & 178.81 & 184.81 \\
\hline 3 & Circular & 1.72 & 20.53 & 8.37 & 9.56 & 232.06 & 238.25 \\
\hline 4 & Circular & 0.0 & 65.71 & 0.00 & 12.68 & 253.57 & 259.72 \\
\hline 5 & Circular & 0.0 & 84.34 & 0.00 & 12.90 & 262.29 & 268.44 \\
\hline
\end{tabular}

Vapour Pressure Deficit (VPD)

In the case of this variable it was also found that the circular model was the theoretical semivariogram model that fitted the experimental data (Table 4). The values of $a$ oscillated between 9.72 and $13.77 \mathrm{~m}$. Likewise, ratio values of $c_{0} / c_{1}$ lower than $25 \%$ again indicate that there is spatial dependence.

Table 4. Parameters of the selected theoretical semivariogram model and its fit quality measures (Akaike - AIC and Bayesian - BIC information criteria) for the evaluated greenhouse VPD data sets.

\begin{tabular}{|c|l|c|c|c|c|c|c|c|}
\hline Group & Model & Nugget $\left(\boldsymbol{c}_{\boldsymbol{0}}\right)$ & Sill $\left(\boldsymbol{c}_{\boldsymbol{l}}\right)$ & $\left(\boldsymbol{c}_{\boldsymbol{0}} \boldsymbol{c}_{\boldsymbol{l}} \mathbf{( \% )}\right.$ & Range $(\boldsymbol{a}, \mathbf{m})$ & AIC & BIC \\
\hline 1 & Circular & 0.0 & 0.001 & 0.00 & 12.97 & -115.51 & -109.55 \\
\hline 2 & Circular & 0.0 & 0.003 & 0.00 & 13.77 & -96.35 & -90.37 \\
\hline 3 & Circular & 0.001 & 0.028 & 3.57 & 9.72 & -41.36 & -35.13 \\
\hline 4 & Circular & 0.0 & 0.033 & 0.00 & 12.55 & -12.21 & -5.99 \\
\hline 5 & Circular & 0.0 & 0.052 & 0.00 & 12.95 & 3.26 & 9.42 \\
\hline
\end{tabular}

\section{Prediction}

The prediction of the analyzed variables for nonsampled points inside the greenhouse was made by means of the ordinary kriging method. These estimates are a function of the results of the adjustment of the theoretical semivariograms, so their validity is given by the quality of the adjustment of the theoretical semivariograms.

\section{Temperature}

The contour plots obtained for this variable in each radiation group allow us to observe their spatial behavior (Figure 6A-E). For the group of radiation 1 that corresponds to the night hours, an average value of the temperature inside the greenhouse of $11.1^{\circ} \mathrm{C}$ can be obtained, with some small areas in relation to the area of the greenhouse 
where the temperature presented an average value of 12.6 ${ }^{\circ} \mathrm{C}$ in the central zone of the greenhouse, for radiation group 2 the average temperature obtained was $12.5{ }^{\circ} \mathrm{C}$ and the difference between the coldest and hottest areas of the greenhouse was $2.2{ }^{\circ} \mathrm{C}$, with the coldest areas located over the areas near the side vents and the hottest areas in the central zone of the greenhouse (Figure 6AB). A similar behavior was obtained for group 3 where the average temperature was $16.5^{\circ} \mathrm{C}$ with cold areas with a lower value of $1.3{ }^{\circ} \mathrm{C}$ and warmer areas with a higher value of $1.7{ }^{\circ} \mathrm{C}$ (Figure 6C). On the other hand, for group 4 and 5 the average temperature was 18.1 and $19.2{ }^{\circ} \mathrm{C}$ respectively with more pronounced thermal differentials between the coldest and hottest point of 3.4 and $6.1{ }^{\circ} \mathrm{C}$ respectively (Figure 6D-E). In general terms, the higher the level of radiation in the external environment, the greater the thermal heterogeneity generated inside the greenhouse. This type of behavior will influence the growth and development of rose plants, since it is a factor that affects phenomena such as photosynthesis and transpiration, which are relevant to the final yield of the crop in terms of both quantity and commercial quality of the final product, in the case of the rose the size and diameter of the stem, and the size, color and degree of consistency and opening of the flower head (In et al., 2016; Lee et al., 2019).
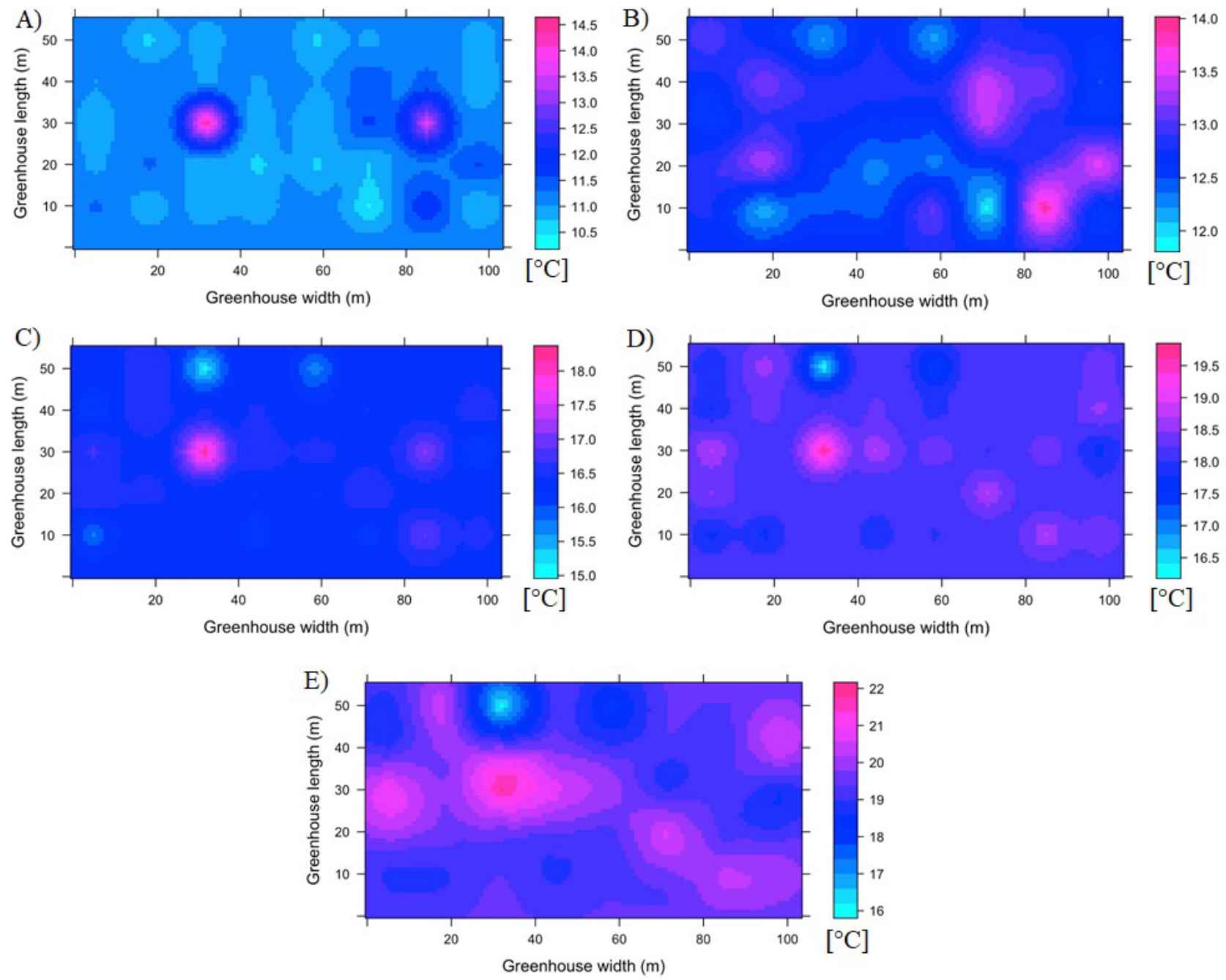

Figure 6. Prediction of temperature $\left[{ }^{\circ} \mathrm{C}\right]$ at unsampled points in the greenhouse assessed by radiation groups, (A) group 1, (B) group 2, (C) group 3, (D) group 4 and (E) group 5. 


\section{Relative humidity}

The spatial variations of the relative humidity during the night hours were relatively low except for an area located towards the front and center of the greenhouse where an area with a humidity level of $89 \%$ was estimated, when the average relative humidity value for the night was $96.3 \%$ (Figure 7A). This same heterogeneous behavior is observed for radiation group 2 where the spatial variation reached a difference of $13.6 \%$ between hot and cold points within the greenhouse (Figure 7B). For radiation intensity levels 3 and 4, there is non-homogeneous behavior in the central zone of the greenhouse, the average humidity values were 81.5 and $78 \%$ respectively, with spatial variations of 13.2 and $25.3 \%$ for each level (Figure 7C-D). For level 5 of radiation, the spatial behavior was maintained, obtaining an average relative humidity of $76.7 \%$ and a horizontal variation of $30.4 \%$ between the hot and cold points inside the greenhouse (Figure 7E). Again, the higher the level of external solar radiation, the more relevant is the degree of horizontal spatial variation of relative humidity. This is certainly not an optimal scenario for production in this type of greenhouse where the management of cultural, irrigation and fertilization tasks are established for an area that is assumed to be homogeneous, as was demonstrated in a study carried out by Fatnassi et al. (2015) there is a possibility that under this type of behavior there are areas in the greenhouse where the microclimate conditions allow the establishment of relevant pests such as trips (Frankliniella occidentalis).
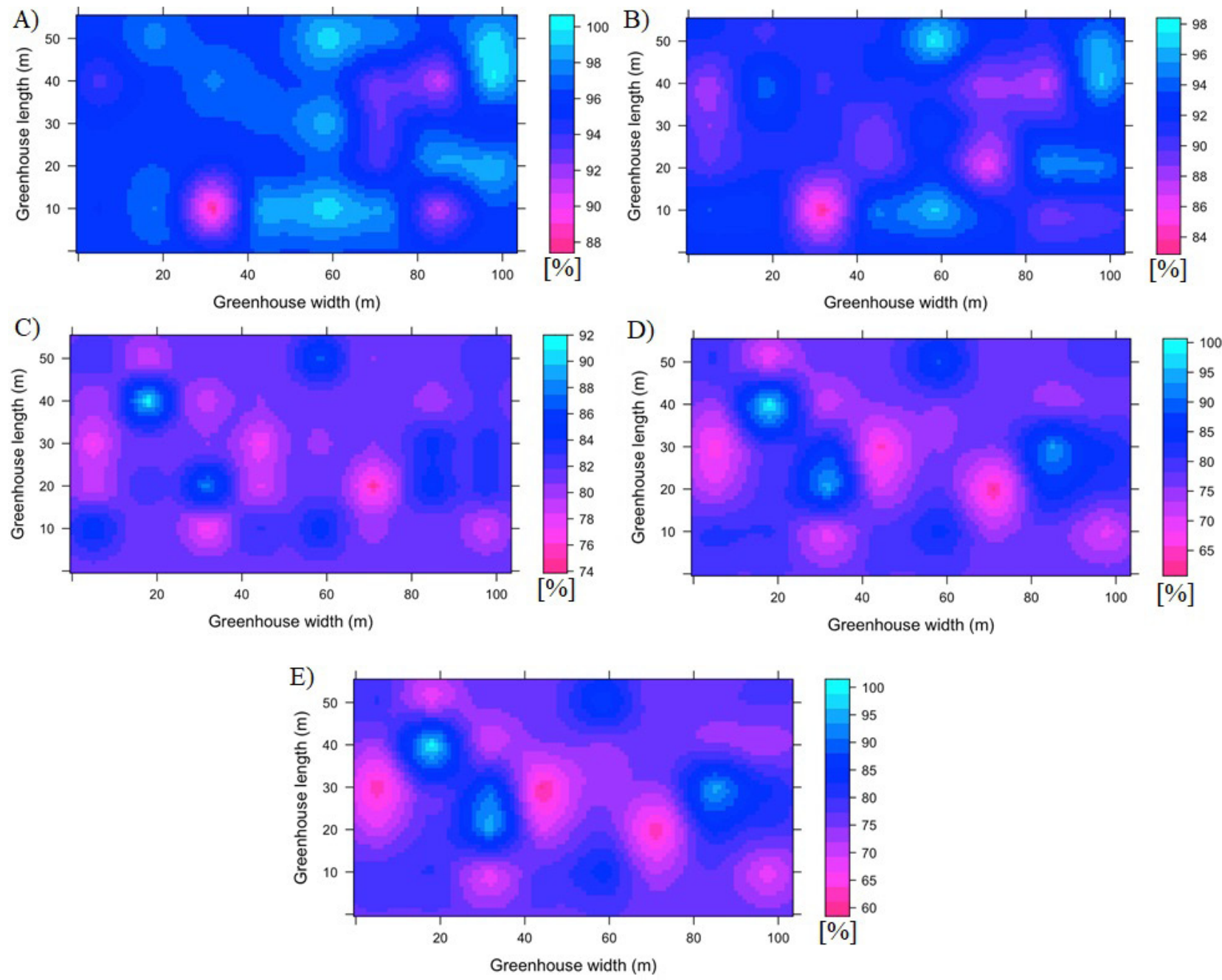

Figure 7. Prediction of relative humidity [\%] in non-sampled points of the greenhouse evaluated by radiation groups, A) group 1, B) group 2, C) group 3, D) group 4 and E) group 5. 
Vapour Pressure Deficit (VPD)

The graphs for the VPD estimates at the non-sampled points present a spatial trend very similar to that observed for the relative humidity variable, because there is a strong correlation between these variables (Figure 8A-E). In general it is observed that the values of VPD are low for the first 3 levels of radiation, the average values obtained were $0.05,0.14$ and $0.34 \mathrm{kPa}$ respectively, values that are below the minimum recommended for the interior of a greenhouse with the presence of plants that is $0.4 \mathrm{kPa}$, in a previous section we mentioned the negative effects that this behavior generates on the growth and development of the plants, in the specific case of the rose it should also be considered that it has been verified that the agricultural production under these conditions of low VPD generates accelerated losses of water after the harvest, which affects considerably the longevity of the plants and their life of vase (Carvalho et al., 2016, 2017; Fanourakis et al., 2016; In and Lim, 2018). On the other hand, as solar radiation levels and the consequent increase in temperature inside the inverter increased, higher VPD values were obtained, as is the case with radiation levels 4 and 5 where the average VPD value was 0.51 and $0.62 \mathrm{kPa}$ respectively (Figure 8D-E).
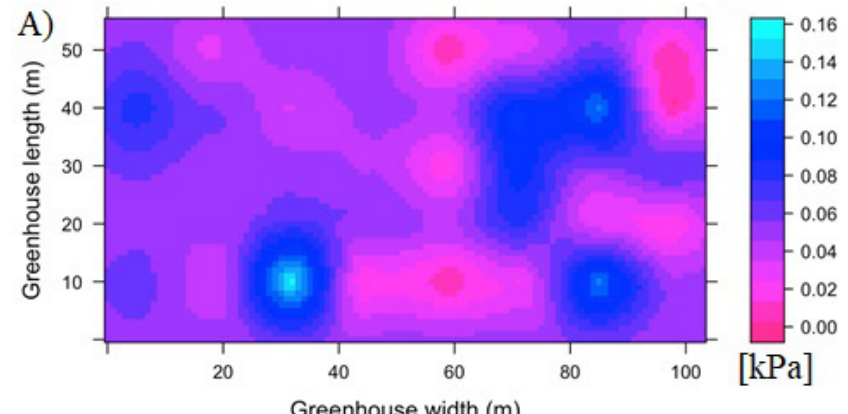

C)

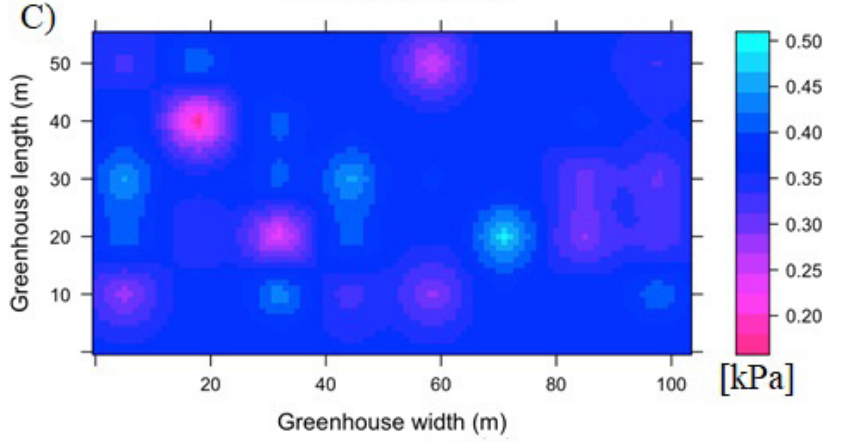

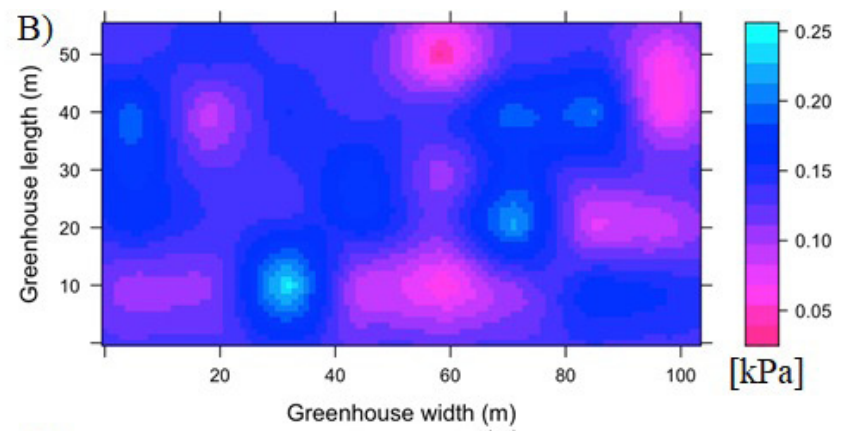

D)

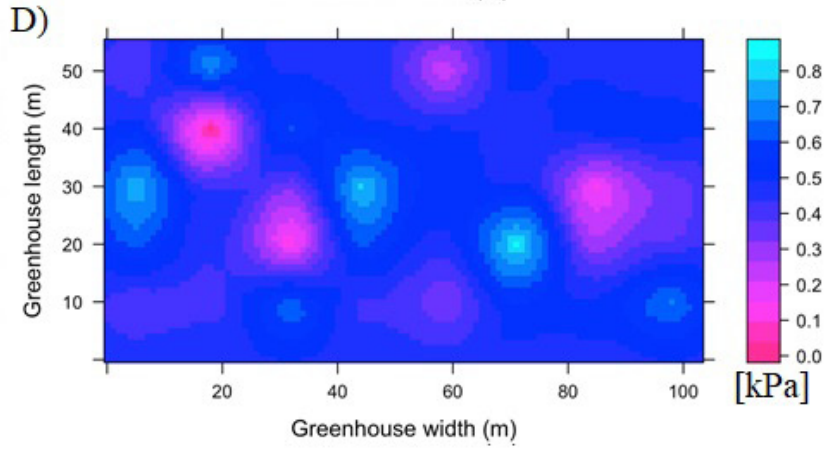

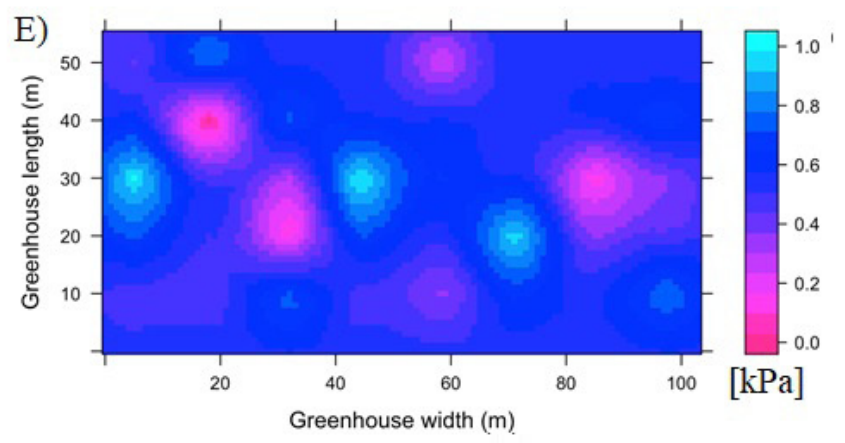

Figure 8. Prediction of the vapour pressure deficit $[\mathrm{kPa}]$ at unsampled points of the greenhouse assessed by radiation groups, A) group 1, B) group 2, C) group 3, D) group 4 and E) group 5. 


\section{Conclusions}

In this research, it was found that the behavior of temperature, relative humidity and VPD inside the greenhouse, as well as the spatial distribution of these variables is related to the intensity of solar radiation in the outside environment. The behavior of temperature and humidity was quite heterogeneous, finding differentials between areas inside the greenhouse of $6{ }^{\circ} \mathrm{C}$ and $30.4 \%$. Finally, if we take as a reference the optimum temperature and relative humidity conditions for rose production reported by various authors in the bibliography consulted, it can be mentioned that for the multi-tunnel greenhouse the temperature behavior is acceptable for the day period and inadequate for the night period, while the humidity and VPD values are outside the range for both day and night. Therefore, the authors recommend that producers should look for alternatives to implement sustainable climate strategies that allow for an increase in temperature levels and a decrease in relative humidity, which could have a positive impact on rose production and the country's ornamental sector.

\section{Author contribution}

E.A.V.M. ${ }^{0000-0003-1860-5932}$ : idea creation, experimental monitoring, data analysis and collection, data analysis, preparation of the manuscript. C.R.B.A. ${ }^{0000-0003-0230-326 x}$ : installation of the experiment, preparation of the manuscript and analysis of results.

\section{Acknowledgements}

The present study was funded by the Servicio Nacional de Aprendizaje (SENA), la Asociación Colombiana de Exportadores de Flores (Asocolflores) y al Centro de Innovación de la Floricultura Colombiana (Ceniflores) through the project "Generación de una herramienta de diseño u optimización de ventilación natural de los invernaderos dedicados a la producción de flores de corte en cuatro subregiones de la Sabana de Bogotá, mediante el uso de herramientas de simulación basadas en la técnica Dinámica de Fluidos Computacional (CFD)".

\section{References}

AHEMD, H.A.; AL-FARAJ, A.A.; ABDEL-GHANY, A.M. Shading greenhouses to improve the microclimate, energy and water saving in hot regions: A review. Scientia Horticulturae, v.201, 36-45, 2016. DOI: https:// doi:10.1016/j.scienta.2016.01.030.

BALENDONCK, J.; SAPOUNAS, A.A.; KEMPKES, F.; VAN OS, E.A.; SCHOOR, R.; VAN TUIJL, B.A.J.; KEIZER, L.C.P. Using a wireless sensor network to determine climate heterogeneity of a greenhouse environment. Acta Horticulturae, n.1037, 539-546, 2014. DOI: https://doi:10.17660/ActaHortic.2014.1037.67.
BAUTISTA, J.P., BARBOSA, H.; URIBE-VÉLEZ, D. Prototipo de formulación a base de Rhodotorula mucilaginosa para el control de Botrytis cinerea en Rosas. Revista Colombiana de Biotecnologia, v.18, n.2, 13-23, 2016. DOI: https://doi:10.15446/rev.colomb.biote. v18n2.55826.

BOJACÁ, C.R.; GIL, R.; COOMAN, A. Use of geostatistical and crop growth modelling to assess the variability of greenhouse tomato yield caused by spatial temperature variations. Computers and electronics in agriculture, v.65, n.2, 219-227, 2009a. DOI: https://doi: 10.1016/j.compag.2008.10.001.

BOJACÁ, C.R.; GIL, R.; GÓMEZ, S.; COOMAN, A.; SCHREVENS, E. Analysis of greenhouse air temperature distribution using geostatistical methods. Transactions of the ASABE, v.52, n.3, 957-968, 2009b. DOI: https:// doi: $10.13031 / 2013.27393$.

CAMBARDELLA, C.A.; MOORMAN, T.B.; PARKIN, T.B.; KARLEN, D.L.; NOVAK, J.M.; TURCO, R.F.; KONOPKA, A.E. Field-scale variability of soil properties in central Iowa soils. Soil Science Society of America journal, v.58, n.5, 1501-1511, 1994.

CARVALHO, D.R.; VASCONCELOS, M.W.; LEE, S.; KONING-BOUCOIRAN, C.F.; VREUGDENHIL, D.; KRENS, F.A.; CARVALHO, S.M. Gene expression and physiological responses associated to stomatal functioning in Rosa $\times$ hybrida grown at high relative air humidity. Plant Science, v.253, 154-163, 2016. DOI: https://doi.org/10.1016/j.plantsci.2016.09.018

CARVALHO, D.R.; VASCONCELOS, M.W.; LEE, S.; VREUGDENHIL, D.; HEUVELINK, E.; CARVALHO, S.M. Moderate salinity improves stomatal functioning in rose plants grown at high relative air humidity. Environmental and Experimental Botany, v.143, 1-9, 2017. DOI: https://doi: 10.1016/j. envexpbot.2017.07.018.

ČEREKOVIĆ, N.; PAGTER, M.; KRISTENSEN, H.L.; BRENNAN, R.; PETERSEN, K.K. Effects of deficit irrigation during flower initiation of two blackcurrant (Ribes nigrum L.) cultivars. Scientia Horticulturae, n.168, 193-201, 2014. DOI: https://doi: 10.1016/j.scienta.2014.01.039.

CHOAB, N.; ALLOUHI, A.; EL MAAKOUL, A.; KOUSKSOU, T.; SAADEDDINE, S.; JAMIL, A. Review on greenhouse microclimate and application: Design parameters, thermal modeling and simulation, climate controlling technologies. Solar Energy, v.191, 109-137, 2019. DOI: https:// doi: 10.1016/j.solener.2019.08.042. 
CRESSIE, N. Statistics for spatial data. Terra Nova, v.4, n.5, 613-617.1992. DOI: https://doi: 10.1111/j.13653121.1992.tb00605.x.

DENG, Y.; WANG, C.; HUO, J.; HU, W.; LIAO, W. The involvement of $\mathrm{NO}$ in ABA-delayed the senescence of cut roses by maintaining water content and antioxidant enzymes activity. Scientia Horticulturae, v.247, 35-41, 2019. DOI: https://doi: 10.1016/j.scienta.2018.12.006.

DIANO, M.; VALENTINI, M.; SAMELE, P.; DI GESU, I. Exposure to hot environments of horticultural greenhouses workers of the center of Calabria: evaluative comparison methods. Italian Journal of Occupational and Environmental Hygiene, v.7, n.2, 2016. DOI: https://doi. org/10.36125/ijoehy.v7i2.144

DOTTO, M.; CASSOL, D.A.; JÚNIOR, A.W.; CITADIN, I. Indolbutyric acid on rooting of cuttings of mini rose bush. Ornamental Horticulture, v.22, 43-49, 2016.

FANOURAKIS, D.; BOURANIS, D.; GIDAY, H.; CARVALHO, D.R.; NEJAD, A.R.; OTTOSEN, C.O. Improving stomatal functioning at elevated growth air humidity: a review. Journal of Plant Physiology, v.207, 51-60, 2016. DOI: https://doi: 10.1016/j.jplph.2013.01.013

FATNASSI, H.; PIZZOL, J.; BOULARD, T.; PONCET, C.; VOISIN, S.; ZIGLER, M. Dependence of thrips infestation on spatial climate distribution in a rose greenhouse crop. Acta Horticulturae, n.921, 261-266, 2012. DOI: https:// doi.org/10.17660/ActaHortic.2012.927.29.

FATNASSI, H.; PIZZOL, J.; SENOUSSI, R.; BIONDI, A.; DESNEUX, N.; PONCET, C.; BOULARD, T. WithinCrop air temperature and humidity outcomes on spatiotemporal distribution of the key rose pest Frankliniella occidentalis. PloS One, v.10, n.5, 2015. DOI: https://doi: 10.1371/journal.pone.0126655.

FERENTINOS, K.P.; KATSOULAS, N.; TZOUNIS, A.; BARTZANAS, T.; KITTAS, C. Wireless sensor networks for greenhouse climate and plant condition assessment. Biosystems Engineering, v.153, 70-81, 2017. DOI: https:// doi: 10.1016/j.biosystemseng.2016.11.005.

GARCÍA-RUIZ, R.A.; LÓPEZ-MARTÍNEZ, J.; BLANCO-CLARACO, J.L.; PÉREZ-ALONSO, J.; CALLEJÓN-FERRE, Á.J. On air temperature distribution and ISO 7726-defined heterogeneity inside a typical greenhouse in Almería. Computers and Electronics in Agriculture, v.151, 264-275, 2018. DOI: https://doi: 10.1016/j.compag.2018.06.001.
GIL, C.S.; LIM, S.T.; LIM, Y.J.; JUNG, K.H.; NA, J.K.; EOM, S.H. Volatile content variation in the petals of cut roses during vase life. Scientia Horticulturae, v.261, 108960, 2020. DOI: https:// doi: 10.1016/j. scienta.2019.108960.

HUANG, Y.; JIN, Y.; ZHANG, K.; YANG, S. A Method to measure humidity based on dry-bulb and wet-bulb temperatures. Research Journal of Applied Sciences, Engineering and Technology, v.6, n.16, 2984-2987, 2013.

IN, B.C.; LIM, J.H. Potential vase life of cut roses: Seasonal variation and relationships with growth conditions, phenotypes, and gene expressions. Postharvest Biology and Technology, v.135, 93-103, 2018. https://doi: 10.1016/j.postharvbio.2017.09.006.

IN, B.C.; SEO, J. Y.; LIM, J.H. Preharvest environmental conditions affect the vase life of winter-cut roses grown under different commercial greenhouses. Horticulture, Environment, and Biotechnology, v. 57, n.1, 27-37, 2016. https://doi:10.1007/s13580-016-0106-9

ISAAKS, E.H.; SRIVASTAVA, R.M. An Introduction to Applied Geostatistics. Vol.1. New York: Oxford University Press, 1989. 592p.

KONOPACKI, P.J..; TREDER, W.; KLAMKOWSKI, K. Comparison of vapour pressure deficit patterns during cucumber cultivation in a traditional high $\mathrm{PE}$ tunnel greenhouse and a tunnel greenhouse equipped with a heat accumulator. Spanish Journal of Agricultural Research, v.16, n.1, e0201, 2018. https://doi: 10.5424/ sjar/2018161-11484.

KINFE, A.M.; VANTHOOR, B.; VAN'T, B. O. Effect of greenhouse cover spectral properties on rose yield for Ethiopia highland. International Journal of Innovation and Applied Studies, v.9, n.4, 1926-1937, 2014.

LEE, S.Y.; LEE, I.B.; YEO, U.H.; KIM, R.W.; KIM, J.G. Optimal sensor placement for monitoring and controlling greenhouse internal environments. Biosystems Engineering, v.188, 190-206, 2019. https://doi: 10.1016/j. biosystemseng.2019.10.005.

LI, K.; XUE, W.; MAO, H.; CHEN, X.; JIANG, H.; TAN, G. Optimizing the 3D distributed climate inside greenhouses using multi-objective optimization algorithms and computer fluid dynamics. Energies, v.12, n.15, 2873, 2019. https://doi: 10.3390/en12152873. 
LÓPEZ, C.C. Spatial and temporal precipitation distribution analysis at chicú river basin, Bogotá's High Altitude Savannah, Colombia. Perspectiva Geográfica, v.21, n.1, 63-90, 2016.

MA, D.; CARPENTER, N.; MAKI, H.; REHMAN, T.U.; TUINSTRA, M.R.; JIN, J. Greenhouse environment modeling and simulation for microclimate control. Computers and Electronics in Agriculture, v.162, 134142,2019.DOI:https://doi: 10.1016/j.compag.2019.04.013.

MADR. 2019. Cadena de Flores Dirección de Cadenas Agrícolas y Forestales. Cifras sectoriales 2018. Available at: <https://sioc.minagricultura.gov.co/Flores/ Documentos/2019-02-30\%20Cifras\%20Sectoriales.pdf> Accessed november 2019.

MORENO, A.J.; PERDOMO, C.A. Study of climate change in Bogota, using Colombia and Global Temperature Data. International Journal of Applied Engineering Research, v.1, n.13, 11225-11230, 2018.

QIU, L.; ZHANG, M.; JU, R.; WANG, Y.; CHITRAKAR, B.; WANG, B. Effect of different drying methods on the quality of restructured rose flower (Rosa rugosa) chips. Drying Technology, p.1-12, 2019. https://doi.org/10.1080 /07373937.2019.1653318

REID, A. Greenhouse roses for cutflower production. Department of Agriculture and Food, Western Australia, Perth. Bulletin 4738. 2008. Available at: <https:// researchlibrary.agric.wa.gov.au/cgi/viewcontent.cgi?articl $\mathrm{e}=1168 \&$ context $=$ bulletins $>$. Accessed on December 2019 .

REIS, M.V.; FIGUEIREDO, J.R.M.; PAIVA, R.; SILVA, D.P.C; FARIA, C.V.N.; ROUHANA, L. Salinity in rose production. Ornamental Horticulture. v.22, n.2, 228 234, 2016. https://doi.org/10.14295/oh.v22i2.904.

SABERIAN, A.; SAJADIYE, S.M. The effect of dynamic solar heat load on the greenhouse microclimate using CFD simulation. Renewable Energy, v.138, 722-737, 2019. DOI: https://doi: 10.1016/j.renene.2019.01.108.

SHAMSHIRI, R.R.; JONES, J.W.; THORP, K.R.; AHMAD, D.; MAN, H. C.; TAHERI, S. Review of optimum temperature, humidity, and vapour pressure deficit for microclimate evaluation and control in greenhouse cultivation of tomato: a review. International Agrophysics, v.32, n.2, 287-302, 2018. DOI: DOI: https:// doi: 10.1515/intag-2017-0005.
SINGH, M.C.; SINGH, J.P.; SINGH, K.G. Development of a microclimate model for prediction of temperatures inside a naturally ventilated greenhouse under cucumber crop in soilless media. Computers and Electronics in Agriculture, v.154, 227-238, 2018. DOI: https:/doi: 10.1016/j.compag.2018.08.044.

TAKI, M.; AJABSHIRCHI, Y.; RANJBAR, S.F.; ROHANI, A.; MATLOOBI, M. Modeling and experimental validation of heat transfer and energy consumption in an innovative greenhouse structure. Information Processing in Agriculture, v.3, n.3, 157-174, 2016. DOI: https://doi: 10.1016/j.inpa.2016.06.002.

TORRE, S.; FJELD, T. Water loss and postharvest characteristics of cut roses grown at high or moderate relative air humidity. Scientia Horticulturae, v.89, n.3, 217-226. 2001. DOI: https://doi.org/10.1016/S03044238(00)00229-6.

VALENCIA, J.; VÉLEZ, J.; ARÉVALO, J. Evaluation of irrigation in roses in a suitable substrate with three water depths and the percentage of drainage. Agronomía Colombiana, v.36, n.3, 266-273. 2018. DOI: http://dx.doi. org/10.15446/agron.colomb.v36n3.73912

VILLAGRÁN, E.A.; ROMERO, E.J.B.; BOJACÁ, C.R. Transient CFD analysis of the natural ventilation of three types of greenhouses used for agricultural production in a tropical mountain climate. Biosystems Engineering, v.188, 288-304, 2019. DOI: https://doi: 10.1016/j. biosystemseng.2019.10.026.

VILLAGRÁN, E.A.; BOJACÁ, C.R. Study of natural ventilation in a Gothic multi-tunnel greenhouse designed to produce rose (Rosa spp.) in the high-Andean tropic. Ornamental Horticulture. v.25, n.2, 133-143, 2019a. DOI: https://doi.org/https://doi.org/10.14295/oh.v25i2.2013.

VILLAGRÁN, E.A.; BOJACÁ, C.R. Simulacion del microclima en un invernadero usado para la producción de rosas bajo condiciones de clima intertropicaL. Chilean Journal of Agricultural \& Animal Sciences, v.35, n.2, 137-150, 2019b. DOI: https://doi: 10.4067/s071938902019005000308 .

VILLAGRÁN, E.A.; BOJACÁ, C.R. Numerical evaluation of passive strategies for nocturnal climate optimization in a greenhouse designed for rose production (Rosa spp.). Ornamental Horticulture. v.25, n.4, 351-364, 2019c. DOI: https://doi: 10.1590/2447-536X.V25I4.2087. 
VILLAGRÁN, E.A.; BOJACÁ , C.R.; ROJAS, N.A ZHANG, L.; MAKI, H.; MA, D.; SÁNCHEZ-GALLEGO, Determinacion del comportamiento térmico de un J. A.; MICKELBART, M. V.; WANG, L.; JIN, J. Optimized invernadero espacial colombiano mediante dinámica de angles of the swing hyperspectral imaging system for single fluidos computacional. Revista U.D.C.A Actualidad y Divulgacion Cientifica, v.21, 415-426, 2018. DOI: https:// doi.org/https://doi.org/10.31910/rudca.v21.n2.2018.10700. corn plant. Computers and Electronics in Agriculture, v.156, 349-359, 2019. DOI: https:// doi: 10.1016/j. compag.2018.11.030. 